\title{
Chapter 14 \\ Biomass-Based Value Webs: A Novel \\ Perspective for Emerging Bioeconomies in Sub-Saharan Africa
}

\author{
Detlef Virchow, Tina D. Beuchelt, Arnim Kuhn, and Manfred Denich
}

\begin{abstract}
Growing demand for increasingly diverse biomass-based products will transform African agriculture from a food-supplying to a biomass-supplying sector, including non-food agricultural produce, like feed, energy and industrial raw materials. As a result, agriculture will become the core part of a biomass-based economy, which has the potential not only to produce renewable biological resources but to convert this biomass into products for various uses. The emerging bioeconomy will intensify the interlinkages between biomass production, processing and trading. To depict these increasingly complex systems, adapted analytic approaches are needed. With the perspective of the "biomass-based value web" approach, a multi-dimensional methodology can be used to understand the interrelation between several value chains as a flexible, efficient and sustainable production, processing, trading and consumption system.
\end{abstract}

Keywords Biomass-based products • Bioeconomy • Biomass-based value webs • Multi-dimensional methodology $\bullet$ Africa

\section{Challenges for the Food and Agricultural System in Sub-Saharan African Countries}

Although there are examples in Sub-Saharan Africa (SSA) in which countries have been able to improve their food and nutrition security significantly over the last decade (e.g., Ghana), the general trend in Africa is still worrisome. While both the share and the number of undernourished people worldwide declined in recent decades, SSA largely failed to follow this trend. The share of undernourished

D. Virchow $(\triangle) \cdot$ T.D. Beuchelt $\bullet$ M. Denich

Center for Development Research (ZEF), University of Bonn, Bonn, Germany

e-mail: d.virchow@uni-bonn.de; beuchelt@uni-bonn.de; m.denich@uni-bonn.de

A. Kuhn

Institute for Food and Resource Economics, University of Bonn, Bonn, Germany

e-mail: arnim.kuhn@ilr.uni-bonn.de

F.W. Gatzweiler, J. von Braun (eds.), Technological and Institutional Innovations for Marginalized Smallholders in Agricultural Development,

DOI 10.1007/978-3-319-25718-1_14 
people in SSA is around $25 \%$, while in the developing world as a whole, the share of the undernourished is around $14 \%$ (FAO 2013). The dramatic situation has long been disguised by sufficient food production at the global scale, but also by the voicelessness of the rural undernourished. Matters would have been worse if world price levels for cereals and other food had not steadily decreased in real terms since the beginning of the 1970s. Low real food prices made staple food affordable for most urban and rural net consumers, while national production shortfalls could be cushioned by imports. Hence, the African food production and consumption situation was seen as tense, but manageable.

The food price crisis of 2007/08, with the underlying trend of the global supply of agricultural produce no longer satisfying the increasing global demand at low price levels, is challenging the agricultural system in many African countries. The annual increase in productivity in food production in Africa is below the $1.7 \%$ required to meet the goal of feeding Africa's rapidly growing population ${ }^{1}$ (Global Harvest Initiative 2011). Due to depleted soil fertility, average cereal yields in SSA have stagnated since the 1960s at $1 \mathrm{t} \mathrm{ha}^{-1}$, while in South and East Asia, yields now reach 2.5 and $4.5 \mathrm{t} \mathrm{ha}^{-1}$, respectively (Gilbert 2012).

The longer-term effects of food price hikes since 2007 that originated, among other reasons, from an increased demand for non-food biomass world-wide are still uncertain. This demand increase is caused by the subsidized demand for biofuel use in the USA and the EU, rising oil prices (and predicted future scarcities) and the need for substitutes, and steeply rising feed demand in the livestock sector that responds to the growing demand for meat and dairy products in emerging economies (Keyzer et al. 2005; Headey and Fan 2008). These 'megatrends' are unlikely to abate in the near future and will keep crop prices, but also prices for input factors such as land, machinery and fertilizer, at levels never expected at the beginning of the new millennium. Land and water scarcity in major importing regions, higher and more volatile food prices, and the demand for non-food biomass (especially biofuels) have also induced a global run on land resources that focuses on, but is not limited to SSA (Brüntrup 2011; Deininger 2011).

Energy is another important concern: Africa - with approximately $13 \%$ of the world population - consumes only $5.6 \%$ of the global energy (2001 data, UN-DESA 2004). Its per capita energy use of about $41 \%$ of the global average is expected to rise with growing trade, increasing (urban) affluence and developing infrastructure (UN-DESA 2004). Current energy supply in Africa - dominated by traditional biomass sources - is inefficient and non-sustainable (Hiemstra-van der Horst and Hovorka 2009; Arnold and Persson 2004). Tree-based fuels (wood and charcoal) represent, respectively, $53 \%, 78 \%$ and $92 \%$ of total energy consumption in Senegal, Kenya and Tanzania (UN-DESA 2004). Fuelwood is predominantly collected from forests and woodland, which drives deforestation and forest degradation, not to mention the burden on the mainly female work force. Per capita fuelwood production decreased at a similar order of magnitude as food biomass, but

\footnotetext{
${ }^{1}$ From 1.02 in 2010 to 1.56 (2030) and 1.96 billion people in 2050 (UN-DESA 2012).
} 
much less than other non-food crop biomass. Growing populations are currently raising energy demands by $3 \%$ annually. The increasing scarcity of fuelwood and higher prices for fossil fuels, as well as emerging policies for renewable energy, raise demand for alternative energy sources, particularly for modern biofuels (Popp et al. 2014). Accordingly, large-scale commercial biofuel production schemes are under development (Brüntrup and Herrmann 2010; Deininger 2011).

The nexus between biofuel production and food security depends heavily, among other factors, on the type of biomass and use (local, national, for export), size of production, owner of production/production structure (smallholders, large-scale plantations), location of processing, employment possibilities, policies and regulations (weakly regulated or not), and, thus, on the local and national context (see, e.g., Amigun et al. 2011; Baffes 2013; Deininger 2011; German et al. 2013; Giampietro and Ulgiati 2005). There are signs that positive effects from introducing biomass crops, in particular on marginal land, can be expected, with increased direct farming income, more off-farm income opportunities, and positive infrastructure and technology spillovers (Lynd and Woods 2011), especially when directed at the smallholder sector with local processing and consumption (Dufey et al. 2007). However, negative effects of biofuel crops have also been reported, such as increased food insecurity, loss of access to land, no additional employment opportunities, only short-term casual labor contracts with unclear conditions, and unfulfilled promises regarding employment and service provision (Deininger 2011; Dufey et al. 2007; Mohr and Raman 2013). Second generation biofuels, e.g., generated through the enzymatic breakdown of cellulose, pyrolysis or gasification, are likely to be more compatible with food production, since they can also use non-edible parts of food crops, by-products of agriculture and forestry, as well as municipal and construction waste. They, thus, compete less for land and food than first generation biofuels (Amigun et al. 2011; Dufey et al. 2007; Naik et al. 2010; Thompson and Meyer 2013).

In general, availability, use of and access to food in SSA must be considerably improved in the coming decades. In addition to increasing the productivity of agriculture and, hence, food availability, income opportunities need significant expansion to ensure access to food. African countries also have to find solutions to deal with increasing foreign and domestic large-scale investment in their agricultural sectors, especially for export-oriented biofuel production, and the consequences of rising land demand and prices.

Agricultural growth is critical for Africa's economic and social development because of its contribution to food security, employment, income, and wealth creation, thereby enabling more people to live food-secure by making a living through working in the agricultural sector without producing food themselves. This increasing pressure on African agriculture seems to over-stretch its current production potential. A closer look at agricultural potential in Africa, however, leads to the insight that the increasing demand for food and non-food agricultural produce (biomass) is a unique opportunity for many African countries, given their endowment of natural and human resources. The increasing demand could be used as a driving force to stimulate and intensify economic development and to improve domestic food and nutrition security (Amigun et al. 2011; Dufey et al. 2007). 


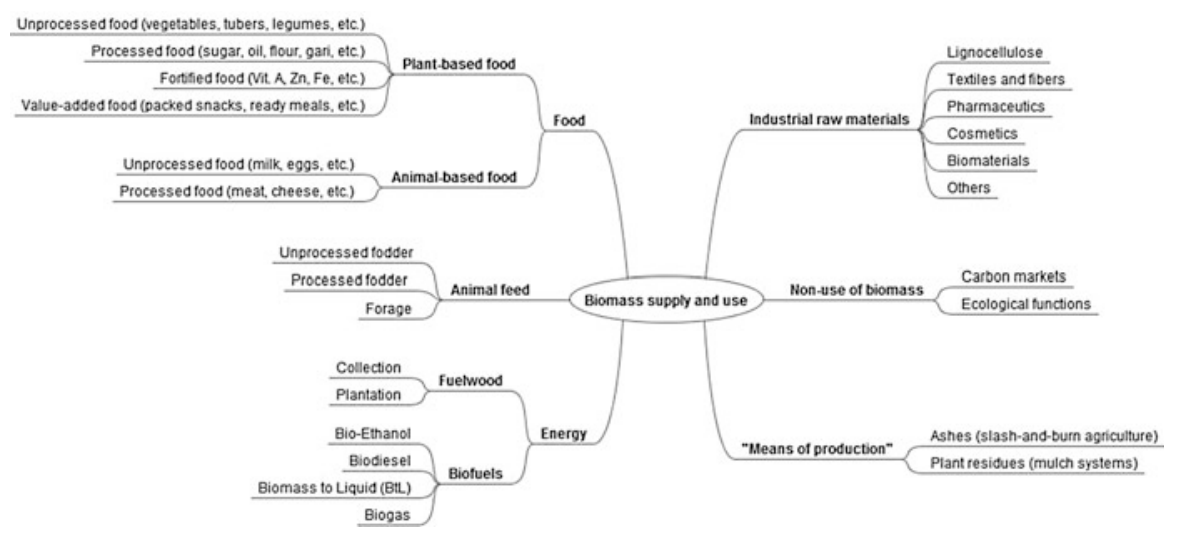

Fig. 14.1 Biomass supply and use

\section{Africa's Biomass Potential}

Biomass is biological material from living or recently living organisms. As a renewable resource, it is expected to play an increasing role in the future economies of both low- and high-income countries. It is roughly classified into food, feed, sources of energy and industrial raw materials (Fig. 14.1). Additionally, on-farm or in the cultural landscape, there is also unused biomass that can help generate income through regional or international carbon markets or paid ecosystem services. Another fraction of biomass can be converted to mulch to manage soil fertility or to ashes (slash-and-burn agriculture) to produce crops under resourcepoor conditions.

Sub-Saharan Africa, in particular, has a high potential to produce plant biomass (Popp et al. 2014). The total net primary production (NPP) ${ }^{2}$ of its land area amounts to 23.8 billion tons per year (Western Europe 3.7 billion tons; in both regions it is $\sim 10 \mathrm{t} \mathrm{ha}^{-1} \mathrm{yr}^{-1}$; Krausmann et al. 2008). This quantity sums up the plant biomass of all different types of vegetation cover, such as forests, savannas and cropland. Krausmann et al. (2008) report that, in the year 2000, 3.6 billion tons (15\%) of the continent's NPP was appropriated by humans, as compared to 1.3 billion tons in Western Europe (35\%). In SSA, half of the biomass flow influenced by humans (1.8 billion tons) is destroyed by deliberately set fires (in W. Europe $<1 \%$ ), predominantly in savanna areas. Biomass imports to and exports from SSA are low and roughly balanced, while Western Europe's biomass imports and exports are 12 times higher than Africa's, and imports exceed exports (Krausmann et al. 2008). Africa has vast land reserves and unused yield potential (Bruinsma 2009). There are limits, however, to the potential of currently unused land from

\footnotetext{
${ }^{2}$ Net primary production (NPP) is the difference between the biomass that plants produce in an ecosystem and the biomass they lose due to metabolic processes (respiration).
} 
environmental perspectives due to important functions of tropical forests and wetlands, biodiversity issues, and high-carbon ecosystems where greenhouse gas emissions larger than the savings could occur upon conversion (Popp et al. 2014).

Focusing on the production and processing of both food and non-food biomass from locally adapted crops within flexible, efficient and sustainable production, processing, trading and consumption systems (hereinafter referred to as "biomassbased value webs") can offer pathways to improve food security and generate jobs and income, particularly in rural areas, to reduce the non-food import bill and even generate urgently needed export earnings, and to maintain environmental assets (Poulton et al. 2006). At first sight, non-food biomass production competes with food crops and feed for land and other resources. However, even within a food security focus, we believe it to be useful to drop the distinction of 'food versus non-food crops', as (1) many crops can be used for both food and non-food purposes and (2) non-food biomass helps generate income, which improves access to food.

Trends in other world regions in comparable geographic latitudes also reveal that neglecting non-food crop biomass is no guarantee for food security. For instance, countries across Asia have managed to increase both the production of food and non-food biomass, resulting in higher agricultural and overall economic growth. This suggests that substantial synergy effects can be harnessed in coordinated, efficient food and non-food biomass production. By contrast, SSA lags behind not only in growth rates of food crop production per capita, but even more so in the production of non-food crop biomass (Fig. 14.2).

\section{The Emerging Bioeconomy}

The expected trends in demand for more and more diverse biomass-based products from agricultural land will transform agriculture from a food-supplying to a biomass-supplying sector. This development, which is taking place at different speeds in different countries, has implications for the agricultural sector as a whole. Agriculture will become the core part of a biomass-based economy which comprises farms as producers, as well as the industrial sector and their associated services that produce, process, distribute, consume or in any way use biological resources (Bioeconomy Council 2011).

The application of the bioeconomy concept means transforming "life science knowledge into new, sustainable, eco-efficient and competitive products" (OECD 2008). This is the specific advantage, but also the challenge for African countries: It is the potential not only to produce renewable biological resources but to convert this biomass into products for various uses (such as food, feed, bioenergy and bio-based industrial products), and thereby capture an increasing share of added value. This is relevant for their exports - instead of low-value biomass raw commodities, high value products are exported - but also for the domestic economy: Through value-adding processes, employment and income opportunities can be generated. Inefficient and unsustainable products and consumption patterns can 


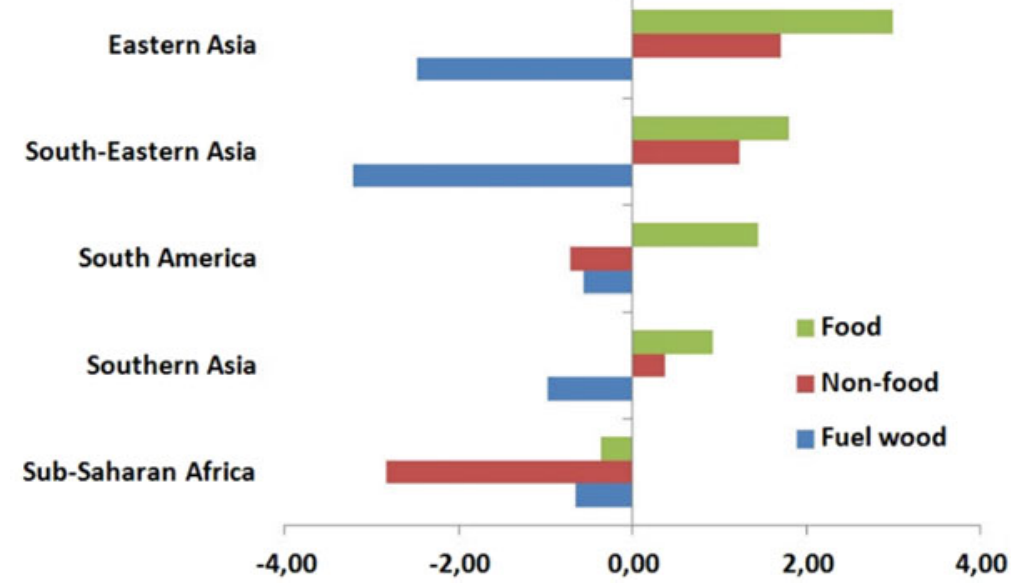

Fig. 14.2 Average annual growth rates of food, non-food, and fuelwood biomass production per capita for selected world regions, 1970-2010 (Source: FAOSTAT Online Database 2012)

be transformed, e.g., a more efficient and less harmful use of fuelwood. Through replacing resource-intensive and environmentally harmful processes through biological processes and new technologies, low-income countries can grow out of the dependency on fossil energy resources, which have to be imported for high value, freeing foreign exchange for other investments. Finally, new and high-value products can be created and utilized on the domestic as well as on the international market.

Together with the transformation from an oil-based to a biomass-based industry, low-income and mainly fossil-oil poor countries will have the opportunity to improve their trade balances by importing less and instead using biomass themselves, including the export of more high-value biomass products. The challenge will be to overcome the traditional division of labor in which low-income countries produce the biomass, while the crucial value addition through processing takes place in high-income biomass-dependent countries (Charles et al. 2007). So many African low-income, but biomass-rich countries have the potential to not only meet their own future demand for biomass-based raw materials (including food) but also to provide high-income and often biomass-dependent countries with biomass (raw and processed) products. For instance, to pursue its bioeconomy strategy, densely populated regions like Europe, being net-consumers, depend on large biomass imports (Erb et al. 2009).

Taking into account that most countries in Africa suffer under a serious unemployment and underemployment problem (AfDB 2013) and that agriculture in Africa will develop to larger management units with a gradual decline in job opportunities at the farm level, alternative and new job opportunities, especially in rural areas, are crucial. With the emerging bioeconomy, rural development opportunities create agricultural employment, and livelihoods are improved through involving small-scale farmers in the production, locating conversion 
facilities near the feedstock sources in rural areas, and focusing on small-scale processing and, especially, local consumption (Dufey et al. 2007).

Despite these advantages, in Africa, only the Republic of South Africa has devised a bioeconomy strategy so far, whereas outside Africa, this has happened in numerous other developing countries (Goh 2013). However, the shift from an economy mainly using oil-based raw materials to an economy based on renewable resources requires a change of existing approaches to production, consumption, processing, storage, recycling and disposal of goods, and the establishment of some guiding principles. These include, as spelled out in the German bioeconomy strategy, the primacy of food security, the sustainable utilization of natural resources and the environment as a whole, and, finally, the compliance with standards of social responsibility. To ensure that the shift to bioeconomies benefits poor and marginalized farmers and other rural stakeholders, the human and social dimensions also need to be considered (Mohr and Raman 2013). Thus, not only technological approaches but also social aspects, which ensure equitable access to ownership and value along the various biomass value chains, including a fairer income distribution, are required. A biomass-based industry is not necessarily an effective means to link smallholders and the informal economy with the formal economy; adequate policies and support structures are important for fostering this process (Dufey et al. 2007). Furthermore, establishment of a functioning bioeconomy relies strongly on the ecological service function of ecosystems emphasized by the Millennium Ecosystem Assessment (MEA 2005).

\section{The Bioeconomy Will Intensify the Ties Between Biomass Production and Processing}

The change of existing technological approaches will imply new and more efficient ways of utilizing biomass, mainly in production and processing, but also in consumption and disposal. The cascading and coupled use of biomass especially will significantly reduce the final "waste", with the ultimate goal of a "zero waste" biomass use.

The increasing demand for diverse biomass products and the intensified utilization of cascading and coupled effects is creating a new, more complex demand structure for biomass products which will determine the biomass production and processing structure. We assume that more and more different biomass resources will be used in the future. To satisfy this increasingly differentiated demand for biomass products, the ties between biomass production and processing will have to be intensified. Furthermore, especially in the processing and trading segment, there will be room for innovations to increase its productivity and efficiency. Consequently, the complexity of value chains of agricultural products is increasing significantly. As described above, the demand side for different biomass types will branch out, with impacts at the handling, processing and trading level leading 
to an augmented diversity of activities. An example is the current research into second generation biofuels. So-called bio-refineries can simultaneously produce a large range of products, such as fuels, different chemicals and materials, including fertilisers and food ingredients, from many different sources of biomass, including agricultural by-products, residues and waste (Antizar-Ladislao and Turrion-Gomez 2008; Naik et al. 2010). This is an excellent example of how different value chains merge and become linked at one point. However, bio-refineries are complex, highly capital- and knowledge-intensive, and need a vast amount of reliable biomass input. Though it is less directly in conflict with food production, it still may create conflicts for food, feed and fuel requirements of the poor rural population who have used these resources - often for free - and may face difficulties in replacing them (Mohr and Raman 2013). For the poor rural population, bioenergy options, such as small- and medium-scale biogas or gasifiers, and power generators operating with locally available biomass sources, such as biogas from manure and agricultural and forestry by-products, may have a better potential to provide economical and reliable energy services (Antizar-Ladislao and Turrion-Gomez 2008).

The closer ties between biomass production, processing and trading, but also demand and consumption, will lead to an increased merging of the different value chains, forming a partly open system. Especially at the handling, processing and trading level, the feedback loops and cascading effects for utilizing and reutilizing biomass will link or merge existing value chains. The cascades of use and linkingup of value chains can improve resource efficiency, reduce possible areas of competition between uses, and make use of innovation potential (BMEL 2014; BMBF 2011). When, for instance, the bioenergy purchaser (be it for the energy market in Lagos or international markets) wants to buy bioenergy, s/he will be increasingly less interested in whether the biomass source of the bioenergy (in kind of charcoal, for instance) originates from trees or shrubs, or from residues, or other parts from cassava, maize, etc.; the purchaser is mainly interested in buying cheap units of kilojoule. Hence, the charcoal producer, in future, will be interested in optimizing benefits by looking for the biomass resources, which enable him/her to produce charcoal with an optimal cost-benefit ratio.

\section{Change Perspectives Towards an Innovative Approach: Biomass-Based Value Web}

Improving food security in Africa is determined through complex and interrelated constraints in availability, access and utilization of food (Hammond and Dubé 2012). To address these constraints, a systems approach is required that matches the complexities (von Braun 2009). Neither a simple agricultural commodity approach nor a non-agricultural industrialization and income generation approach would help overcome food insecurity and its consequences for undernourishment 
and health. To address the various dimensions of food security while moving towards a sustainable economy based on biological raw materials, completely new approaches to research and development, production, and economy are necessary (Naik et al. 2010) that also consider human and social aspects (Mohr and Raman 2013).

Extending Porter's (1985) classical, firm-based value chain, three main strands of concepts evolved "to explain how global industries are organized and governed, and how, in turn, those relationships affect the development and upgrading opportunities of the various regions and firms involved" (Coe et al. 2008, p. 267). These concepts are the global commodity chain, the global value chain and the global production networks (Coe et al. 2008). However, it is no longer sufficient to analyse the system by following the conventional, more vertical and linear, mainly productfocused commodity or value chain approach. Analytical perspectives are needed which cover the complex pathways of biomass and integrate social, economic and environmental perspectives (Mangoyana et al. 2013). This adds a new perspective to the concepts of value chains and global production networks. Here, the holistic concept of biomass-based value webs becomes instrumental.

A biomass-based value web approach utilizes the 'web perspective' as a multidimensional framework to understand the interrelation and linkages between several value chains and how they are governed. Like global production networks, the web approach sees the process of activities that result in a final product as one "in which the flows of materials, semi-finished products, design, production, financial and marketing services are organized vertically, horizontally and diagonally in complex and dynamic configurations" (Henderson et al. 2002, p. 444). Instead of depicting the pathway of one product, the web approach captures the manifold products which are derived from one biomass raw product, but also looks at the whole product mix produced on family farms, the different value chains the households participate in and how they are or could be linked. The web perspective helps to explore synergies between these value chains, identify inefficiencies in biomass use and pinpoint potential for sustainable productivity increases in the entire biomass-based value web of a defined local, national or international system. It includes the analysis of existing and potential recycling processes and cascading uses during the processing phase of biomass, which opens new opportunities to locally capture more of the value-added or create new value (Smith et al. 2000). The cascades of use and interlinking of value chains are instrumental to increasing the efficiency of resources and the sector, reducing possible areas of competition between uses and making use of innovation potential.

An exemplary, very basic biomass-based value web, identified at a stakeholder workshop in Ghana, illustrates basic value web features. Starting from the production/supply side, a crop can be utilized in various ways (e.g., cassava as a multipurpose crop is used for food, feed, fuel and fiber), leading to a divergent structure and interaction (especially reflecting the fact that first-level outputs may be fed into another processing after utilization). Looking at the system from the demand side, it is obvious that one product in demand (e.g., feed or energy) can be delivered by very different crops from the supply side, i.e., various supplied products converge 
on one final product. The final product, such as bioethanol, is derived through processing several raw materials or their residues, such as rice, cassava, cotton, sugarcane, and forest biomass. This can be done at different processing locations and enterprises or at the same one.

The structural preconditions, power and social relations embedded in the value chains inevitably shape the value webs and impose a path-dependency; they influence as well as constrain the future trajectory of chain development (Henderson et al. 2002). The web perspective also helps to better identify who participates and benefits in the biomass-based economy (e.g., men or women, small or large producers/processors, national or international actors) and who does not, in which activities and processes, and whether and how the actors co-operate and network with each other. This helps to identify missing links or actors, information gaps, and capacity constraints, as well as governance issues and power relations. Who has the power and the ways in which it is exercised is decisive for how and where more value could be added and captured in low-income countries and, thus, key for a more equitable development (Henderson et al. 2002). The analytical approach contributes to identifying profit and other benefit distributions among the different actors and participants in the whole web. Thus, opportunities can be detected where benefits could be better distributed to be more inclusive, especially towards the poor and marginalized, and where access to food through job and income generation can be increased (Bolwig et al. 2010; Kaplinsky 2000).

The value webs enable a GIS-supported mapping of the spatial distribution of ongoing activities in the web. This allows decision-makers to better identify the locations where new investments in biomass technologies will have a favorable social, economic and environmental impact. For example, decentralized, community-oriented systems contribute to local sustainable development while centralized production systems rather allow for capturing economies of scale (Mangoyana et al. 2013). Using the web approach can also help to analyze and mitigate existing or potential trade-offs of technological innovations in the web. For example, through purposefully introduced cascading uses of cassava peel and maize residues for biochar, jobs could be created which were lost when a processing plant was modernized. Or investments could be directed towards enhanced biomass processing facilities at a women's cooperative to compensate for their current marginalization in the employment market.

\section{Conclusions and Implications}

As discussed in this chapter, agricultural growth is critical for Africa's economic and social development because of its contribution to food security, employment, income, and wealth creation. Based on the high potential of biomass in Africa, the increasing demand for biomass as food and non-food agricultural produce is a unique opportunity for many African countries and their populations rather than a risk to their food and nutrition security. However, the system productivity of the 
food and agricultural sector in SSA has to be increased by maintaining or even improving the economic viability, social acceptability, environmental resilience and technical appropriateness.

The biomass-based value web is a useful scientific and policy perspective for broad, equitable rural development in investigating the potential for agricultural activities and the related economy of a country or region in view of the challenges of coming decades. Three arguments support this position:

- First, given the background of the food versus non-food production problem, the use and further development of multi-purpose crops allows producers to react flexibly to shifting demands. The value chains of multi-purpose crops, and the various forms of demand (food, feed, energy, industrial material) which are jointly satisfied by diverse crops and/or production systems, strongly resemble a web structure.

- Second, we hypothesize that the organizational features of value webs are inherently flexible and, thus, better suited to a volatile price environment, as compared to the classical linear value chains.

- Third, the web perspective better allows for exploring synergies and identifying inefficiencies in an emerging agro-biomass sector and, thus, could be critical to increasing the sector's efficiency.

Increasing the efficiency and throughput in value chains geared towards an "endproduct" alone, however, carries the risk of overexploiting natural resources. System management must include waste management and recycling to close material cycles. The value web perspective does not only focus on the creation of narrowly defined 'value added' at different stages. It is also the opportunity to look at non-monetary values, such as material flows, conversion ratios or the use of inputs and production factors like labor and capital. Adopting a web perspective is a systems approach by nature.

Biomass demand is increasing worldwide. Increasing the activities of the domestic processing industry for biomass products in Africa and elsewhere requires the political commitment of governments, as well as international support. Technical and physical infrastructure, a skilled labor force, and financial instruments are part of the solution. However, addressing the human and social aspects should not be detached from bioeconomies and biomass development, but rather combined so that it benefits large shares of the poor population, especially in rural areas. Here, social and gender-responsive approaches need to be incorporated in the planning and design of investments from the beginning. Thus, further research and investment in employment-intensive yet capital-saving processing technologies for biomass commodities in developing countries is important to benefit the poor and unemployed women and men. High-capital and technology-intensive investments, like future biorefineries, will only be an option in a few cases. Small systems focusing on local processing and consumption seem to hold far more promise for the benefit of smallholders and marginalized farmers in particular.

The emerging bioeconomies may help low-income, agriculture-dominated countries to generate jobs and income in the biomass producing, processing and 
trading sector, in urban and rural areas. The key challenges are to identify pathways for poor countries and poor producers to take advantage of these opportunities, which types of biomass, processing and technologies offer a realistic chance for biomass producers and processors in these countries, and how, at the same time, food security can be enhanced and poverty reduced. Further knowledge gaps exist where the respective value chains and value webs need adjustment and support to ensure that value addition stays in the producing countries and contributes to improving the livelihoods of farmers, fostering small- and medium-sized processors and generating employment opportunities.

Open Access This chapter is distributed under the terms of the Creative Commons AttributionNoncommercial 2.5 License (http://creativecommons.org/licenses/by-nc/2.5/) which permits any noncommercial use, distribution, and reproduction in any medium, provided the original author(s) and source are credited.

The images or other third party material in this chapter are included in the work's Creative Commons license, unless indicated otherwise in the credit line; if such material is not included in the work's Creative Commons license and the respective action is not permitted by statutory regulation, users will need to obtain permission from the license holder to duplicate, adapt or reproduce the material.

\section{References}

AfDB (2013) African statistical yearbook 2013. African Development Bank Group, Abidjan

Amigun B, Musango JK, Stafford W (2011) Biofuels and sustainability in Africa. Renew Sust Energ Rev 15(2):1360-1372. doi:10.1016/j.rser.2010.10.015

Antizar-Ladislao B, Turrion-Gomez JL (2008) Second-generation biofuels and local bioenergy systems. Biofuels Bioprod Biorefin 2(5):455-469. doi:10.1002/bbb.97

Arnold M, Persson R (2004) Reassessing the fuelwood situation in developing countries. Int For Rev 5(4):379-383

Baffes J (2013) A framework for analyzing the interplay among food, fuels, and biofuels. Global Food Secur 2(2):110-116. doi:10.1016/j.gfs.2013.04.003

BMBF (Federal Ministry of Education and Research) (2011) National Research Strategy BioEconomy 2030: our route towards a bio-based economy. Federal Ministry of Education and Research, Berlin

BMEL (Federal Ministry of Food and Agriculture) (2014) National Policy Strategy on Bioeconomy: renewable resources and biotechnological processes as a basis for food, industry and energy. Federal Ministry of Food and Agriculture, Berlin

Bolwig S, Ponte S, Du Toit A, Riisgaard L, Halberg N (2010) Integrating poverty and environmental concerns into value-chain analysis: a conceptual framework. Dev Policy Rev 28 (2):173-194. doi:10.1111/j.1467-7679.2010.00480.x

Bruinsma J (2009) The resource outlook to 2050: by how much do land, water and crop yields need to increase by 2050? Food and Agriculture Organization of the United Nations, Rome

Brüntrup M (2011) Detrimental land grabbing or growth poles? Determinants and potential development effects of foreign direct land investments. Technikfolgenabschätzung - Theorie und Praxis 20(1):3-12

Brüntrup M, Herrmann R (2010) Bioenergy value chains in Namibia: opportunities and challenges for rural development and food security. In: Darnhofer I, Grötzer M (eds) Proceedings to 9th European IFSA symposium: building sustainable rural futures; the added value of systems approaches in times of change and uncertainty, 4-7 July, Vienna, pp 1461-1472 
Charles MB, Ryan R, Ryan N, Oloruntoba R (2007) Public policy and biofuels: the way forward? Energy Policy 35(11):5737-5746. doi:10.1016/j.enpol.2007.06.008

Coe NM, Dicken P, Hess M (2008) Introduction: global production networks - debates and challenges. J Econ Geogr 8(3):267-269. doi:10.1093/jeg/lbn006

Deininger K (2011) Challenges posed by the new wave of farmland investment. J Peasant Stud 38 (2):217-247. doi:10.1080/03066150.2011.559007

Dufey A, Vermeulen S, Vorley B (2007) Biofuels: strategic choices for commodity dependent developing countries. Common Fund for Commodities, Amsterdam

Erb K, Krausmann F, Lucht W, Haberl H (2009) Embodied HANPP: mapping the spatial disconnect between global biomass production and consumption. Ecol Econ 69(2):328-334. doi:10.1016/j.ecolecon.2009.06.025

FAO (2013) The state of food insecurity in the world 2013: the multiple dimensions of food security. Food and Agriculture Organization of the United Nations, Rome

FAOSTAT (2012) http://faostat.fao.org, accessed Oct 12, 2014

German Bioeconomy Council (2011) Prioritäten in der Bioökonomie-Forschung. Empfehlungen des BioÖkonomieRats. German Bioeconomy Council, Berlin

German L, Schoneveld G, Mwangi E (2013) Contemporary processes of large-scale land acquisition in Sub-Saharan Africa: legal deficiency or elite capture of the rule of law? World Dev 48:1-18. doi:10.1016/j.worlddev.2013.03.006

Giampietro M, Ulgiati S (2005) Integrated assessment of large-scale biofuel production. Crit Rev Plant Sci 24(5-6):365-384. doi:10.1080/07352680500316300

Gilbert N (2012) African agriculture: dirt poor. Nature 483(7391):525-527. doi:10.1038/483525a

Global Harvest Initiative (2011) 2011 GAP report. Global agricultural productivity report. Global Harvest Initiative, Washington, DC

Goh L (2013) Bioeconomy is the way to go. The Star, Malaysia, 20 Oct 2013

Hammond R, Dubé L (2012) A systems science perspective and transdisciplinary models for food and nutrition security. Proc Natl Acad Sci U S A 109(31):12356-12363. doi:10.1073/pnas. 0913003109

Headey D, Fan S (2008) Anatomy of a crisis: the causes and consequences of surging food prices. Agric Econ 39:375-391. doi:10.1111/j.1574-0862.2008.00345.x

Henderson J, Dicken P, Hess M, Coe N, Yeung HW (2002) Global production networks and the analysis of economic development. RIPE 9(3):436-464. doi:10.1080/09692290210150842

Hiemstra-van der Horst G, Hovorka A (2009) Fuelwood: the "other" renewable energy source for Africa? Biomass Bioenergy 33(11):1605-1616

Kaplinsky R (2000) Globalisation and unequalisation: what can be learned from value chain analysis? J Dev Stud 37(2):117-146

Keyzer MA, Merbis MD, Pavel I, van Wesenbeeck C (2005) Diet shifts towards meat and the effects on cereal use: can we feed the animals in 2030? Ecol Econ 55(2):187-202. doi:10.1016/ j.ecolecon.2004.12.002

Krausmann F, Erb K, Gingrich S, Lauk C, Haberl H (2008) Global patterns of socioeconomic biomass flows in the year 2000: a comprehensive assessment of supply, consumption and constraints. Ecol Econ 65(3):471-487. doi:10.1016/j.ecolecon.2007.07.012

Lynd LR, Woods J (2011) A new hope for Africa. Nature 474:20-21

Mangoyana RB, Smith TF, Simpson R (2013) A systems approach to evaluating sustainability of biofuel systems. Renew Sust Energ Rev 25:371-380. doi:10.1016/j.rser.2013.05.003

MEA (Millennium Ecosystem Assessment) (2005) Ecosystems and human well-being: synthesis millenium ecosystem assessment. Island Press, Washington, DC

Mohr A, Raman S (2013) Lessons from first generation biofuels and implications for the sustainability appraisal of second generation biofuels. Energy Policy 63:114-122. doi:10.1016/j. enpol.2013.08.033

Naik SN, Goud VV, Rout PK, Dalai AK (2010) Production of first and second generation biofuels: a comprehensive review. Renew Sust Energ Rev 14(2):578-597. doi:10.1016/j.rser.2009.10. 003 
OECD (2008) Business for development 2008. Promoting commercial agriculture in Africa. OECD Publications, Organisation for Economic Co-operation and Development, Paris

Popp J, Lakner Z, Harangi-Rákos M, Fári M (2014) The effect of bioenergy expansion: food, energy, and environment. Renew Sust Energ Rev 32:559-578. doi:10.1016/j.rser.2014.01.056

Porter M (1985) Competitive advantage: creating and sustaining superior performance. The Free Press, New York

Poulton C, Tyler G, Dorward A, Hazell P, Kydd J, Stockbridge M (2006) All Africa review of experiences with commercial agriculture: summary report. Draft report prepared for the world bank project on competitive commercial agriculture in Africa. Imperial College, London

Smith RW, Broxterman WE, Murad DS (2000) Understanding value webs as a new business modeling tool: Capturing \& Creating Value in Adhesives. The ChemQuest Group, Cincinnati

Thompson W, Meyer S (2013) Second generation biofuels and food crops: co-products or competitors? Global Food Sec 2(2):89-96. doi:10.1016/j.gfs.2013.03.001

UN-DESA (2004) Sustainable energy consumption in Africa. United Nations Department of Economic and Social Affairs, New York

Karekezi S, Wangeci J, Manyara E (2004) Sustainable energy consumption in Africa. UN-DESA Final Report. African Energy Policy Research Network, Nairobi, $54 \mathrm{p}$

UN-DESA (2012) Population division of the Department of Economic and Social Affairs of the United Nations Secretariat: World population prospects: the 2010 revision. UN-DESA, New York

von Braun J (ed) (2009) Food security risks must be comprehensively addressed, IFPRI annual report essay 2008-2009. International Food Policy Research Institute, Washington, DC 